\title{
New Approach for Evaluation of a Watershed Ecosystem Service for Avoiding Reservoir Sedimentation and Its Economic Value: A Case Study from Ertan Reservoir in Yalong River, China
}

\author{
Bilige Sude, ${ }^{1}$ Wu Nan, ${ }^{2}$ Gao Ji-Xi, ${ }^{3}$ Zhang Chen, ${ }^{1}$ Ge Jing, ${ }^{2}$ and Ennaanay Driss ${ }^{4}$ \\ ${ }^{1}$ Institute of Ecology, Chinese Research Academy of Environmental Sciences, Beijing 100012, China \\ ${ }^{2}$ Institute of Ecology, Anhui Academy of Environmental Science, Hefei 230071, China \\ ${ }^{3}$ Nanjing Institute of Environmental Sciences, Ministry of Environmental Protection, Nanjing 210042, China \\ ${ }^{4}$ Woods Institute for the Environment, Stanford University, Stanford, CA 94305-5020, USA \\ Correspondence should be addressed to Bilige Sude, sude@craes.org.cn
}

Received 25 August 2011; Accepted 9 September 2011

Academic Editor: Walter Willms

Copyright (C) 2011 Bilige Sude et al. This is an open access article distributed under the Creative Commons Attribution License, which permits unrestricted use, distribution, and reproduction in any medium, provided the original work is properly cited.

\begin{abstract}
A model was established to simulate an ecosystem service of avoiding reservoir sedimentation and its economic value based on the process of sediment delivery in a watershed. The model included fabricating the watershed of the study reservoir. The sediment retention coefficient of different land cover types were used to simulate the spatial patterns of the annual quantity of the sediment that were prevented from entering the reservoir by the vegetation in each cell followed the flow path in watershed. The economic value of the ecosystem service in this model was determined by the marginal cost of reservoir desilting. This study took the Ertan reservoir as an example. The results showed that most eroded soil was intercepted by different types of ecosystems in the process of sediment delivery in a watershed. The region with a higher quantity of sediment retention was around the reservoir. The absolute quantity of average sediment retention in forestland was lower, so the sediment retention ability of forestland failed to be brought into fullest play in watershed.
\end{abstract}

\section{Introduction}

The erosion of soil and its generation of sediment in a watershed can cause significant sedimentation in associated reservoirs. The subsequent decrease in storage capacity not only decreases the effective operation of the reservoirs but also causes other problems. Sedimentation spread to the upper river regions can affect the environment. Sedimentation in backwater regions can alter the navigational conditions for ships and boats. Sullage at the bottom of reservoirs can cause deterioration in water quality. Extreme build-up of sediment behind a dam wall can threaten the safety of the dam. Reservoir sluicing can change the river course in the lower reaches of a river [1]. Regular sediment removal is a common solution for avoiding long-term sedimentation problems, but it results in a costly maintenance budget. The ecosystem provides a natural service or function of soil retention by using roots to hold soil in place, and the processes of interception, absorption, and saturation can reduce the scouring power of runoff [2]. The service or function of the avoided reservoir sedimentation is a very important aspect of soil retention [3-5].

In China the current approaches to evaluating the efficacy of the ecosystem service for avoiding reservoir sedimentation are all quite similar. They calculate the amount of soil retention in the whole landscape based on the universal soil loss equation (USLE) or the revised universal soil loss equation (RUSLE) and then multiply it by a coefficient $(0.24)$ which is in accordance with the regulations for sediment delivery in China $[3,6]$. The economic value of this service is calculated by a substitute engineering approach based on the unit volume expense of building reservoirs [6]. This approach determines the ecosystem service of the avoided reservoir sedimentation in terms of quantity and value for the whole landscape of the study area. It does not focus on a specific reservoir and the region that generates sediment 
to that reservoir. Therefore, this approach cannot identify the supplier and beneficiary of this service. These results cannot guide decision-making on ecosystem integration management and ecological compensation. The use of the same whole-country coefficient for different areas can lead to inaccurate results for these areas.

The pattern and processes of ecosystem are material base of ecosystem service supply [7]. In a close watershed, the spatial distribution pattern of ecosystem is the carrier of processes which water and sediment delivery together. Any variation of pattern will influence the stochastic ecological processes while many dynamic factors and impelling force that mould pattern are included in the processes of delivery. The function of preventing sediment from entering relative reservoir is represented by the interaction between spatial distribution pattern of ecosystem and processes of sediment delivery in watershed scale. The relative ecosystem service is a kind of representation of the function supplying human welfare and arising therefrom.

In this situation, on the basis of studying in a deep-going way the complicated relationship between the ecosystem pattern and sediment delivery processes, taking patternprocesses-services as its storyline, a quantity model for evaluating the sediment retention on each pixel in the scale of watershed is established by integrating the coefficient that presents the ability of sediment retention on different land cover types. As an example, this investigation applied and testified the model of the Ertan reservoir of the lower Yalong River by using data in 2005. The conjuncted relationship between ability of preventing sediment from entering the reservoir of ecosystem in Yalong River watershed (above Ertan reservoir) and the pattern of land cover was found out. The results not only give guidance to decision-making for selecting the location of the ecological project that will maintain the safety of the Ertan reservoir, but also give some support to building ecological compensation and tradeoff mechanisms between the company that operates the reservoir and the land manager of the watershed.

\section{Study Area and Methods}

2.1. The General Geographic Situation. The Yalong River (drainage basin range: $25^{\circ} 12^{\prime} 22^{\prime \prime} \sim 34^{\circ} 9^{\prime} 22^{\prime \prime} \mathrm{N}, 96^{\circ} 47^{\prime} 23^{\prime \prime} \sim$ $102^{\circ} 42^{\prime} 21^{\prime \prime} \mathrm{E}$ ) is located in the west of Sichuan province and the southeast of Qinghai-Tibet Plateau. It is the biggest anabranch of the Jinsha River. The water resource of the Yalong River is prolific and the fall is quite big. The main and branch rivers both contain abundant hydroelectric resource potential. The length of the main river course is $1571 \mathrm{~km}$ from the river head to the outfall [8]. The area of the drainage basin is about $13.0 \times 10^{4} \mathrm{~km}^{2}$. The natural fall is about $3830 \mathrm{~m}$. The average velocity of flow in the outfall is about $1910 \mathrm{~m}^{3} \cdot \mathrm{s}^{-1}$ while the annual mean amount of runoff is about $600 \times 10^{8} \mathrm{~m}^{3}$. The climate situation is very complex, and the differences at both ground level and higher up are very obvious. The annual mean precipitation varies from 600 to $1800 \mathrm{~mm}$. The main types of vegetation are forest, brush and meadow (see Figure 1). The Ertan power station is the first hydroelectric power station developed on the lower Yalong River. It is a large-scale water control project with comprehensive functions. Power generation is the main purpose of this project which was completed by the end of the 1999. The height of the dam is about $240 \mathrm{~m}$, and the total storage capacity is about $58 \times 10^{8} \mathrm{~m}^{3}$. The shape of the Ertan reservoir area is similar to an asymmetrical tree-like structure and a total area of $101 \mathrm{~km}^{2}$.

Because of the specific environmental conditions of the Yalong River basin, the river course has great potential for sediment delivery. The practice of cutting natural forest, tilling the steep slopes, and overgrazing grassland is very common in the drainage area. Erosion intensity is so acute in the Yalong River basin that it has become the region with the most intense soil and water loss in the Upper Yangtze River [8]. A great deal of sediment is delivered to the river course and the reservoir and has a great influence on the safety and operation of this huge water conservation project.

2.2. The Evaluation Model on Quantity. A great deal of data is processed and can be used for computer animation by integrating the model on biophysical assessment of the avoided reservoir sedimentation with the software of ArcGIS9.2. The specific approach is to use the ArcGIS9.2 as an interface and control platform. The model was established by taking on raster data form. The flow chart of mapping biophysical assessment can be seen in Figure 2.

2.2.1. Identifying the Extent of the Watershed. The watershed is identified as the supply region for the surface and ground water, that is to say the surface and ground watersheds of the water body are considered as a group. The area of the watershed is the total region that can receive precipitation and supply water via river course and all its tributaries [9]. This watershed is the sediment generation region that feeds the mouth of the watershed as defined by the combined water and sediment delivery theory of water erosion.

In order to revise the DEM datum (cell size is $30 \mathrm{~m}$ ), the fill-sinks tool (Fill) in the hydrology tools of the ArcGIS9.2 is used to identify and fill sinks on the DEM datum. The flow direction datum is derived from the revised DEM through the method of eight flow directions (D8). The flow direction datum is used to generate the flow accumulation datum depending on the records of the pixel that other pixels contribute to. Using the tool "snap pour point," it snaps the pour point cell to its high accumulation neighbor by specifying the snap radius depending on the data of flow accumulation and the location of the reservoir. The watershed is established by the tool "watershed" depending on the adjusted pour point and the flow direction [10].

2.2.2. Ascertaining Actual Soil Erosion. USLE is primarily used to forecast the quantity of soil erosion on a gradual sloping field based on an examination of the runoff subdistrict. Experience with this model has found that it is hard to use for middle-sized basins. Since 1980 the GIS has been used to forecast and evaluate the quantity of soil erosion in different sized basins by integrating the USLE 


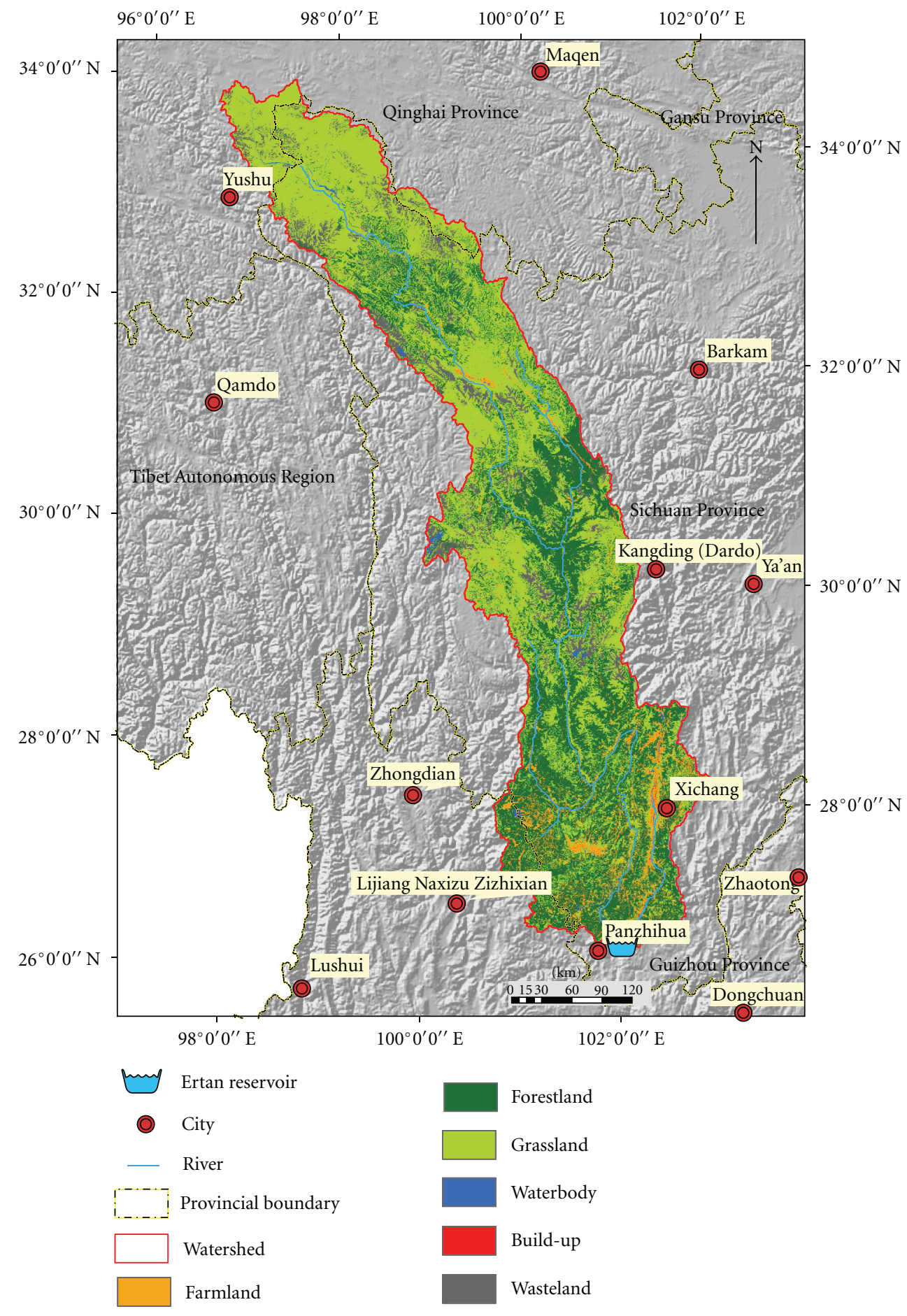

FIgURE 1: The location of the watershed of Ertan reservoir.

[11]. Compared to using traditional centralized methods to predict the quantity of soil erosion, this distributed method can predict the quantity of soil erosion for every pixel because of the spatial analyst function of the raster dataset used in the GIS. It is convenient for finding out the acute soil erosion regions for the area manager who can then put forward the best management practices (BMPs). It can improve the efficiency of prediction and the effective availability of the displayed results [12]. The estimated formula for actual soil erosion takes land cover, management and support practice factors into account:

$$
A_{\gamma}=R \times K \times L S \times C \times P .
$$

In these formulae, $A_{\gamma}$ is the amount of actual soil erosion $\left(\mathrm{t} \cdot \mathrm{hm}^{-2} \cdot \mathrm{a}^{-1}\right), R$ is the rainfall and runoff factor 


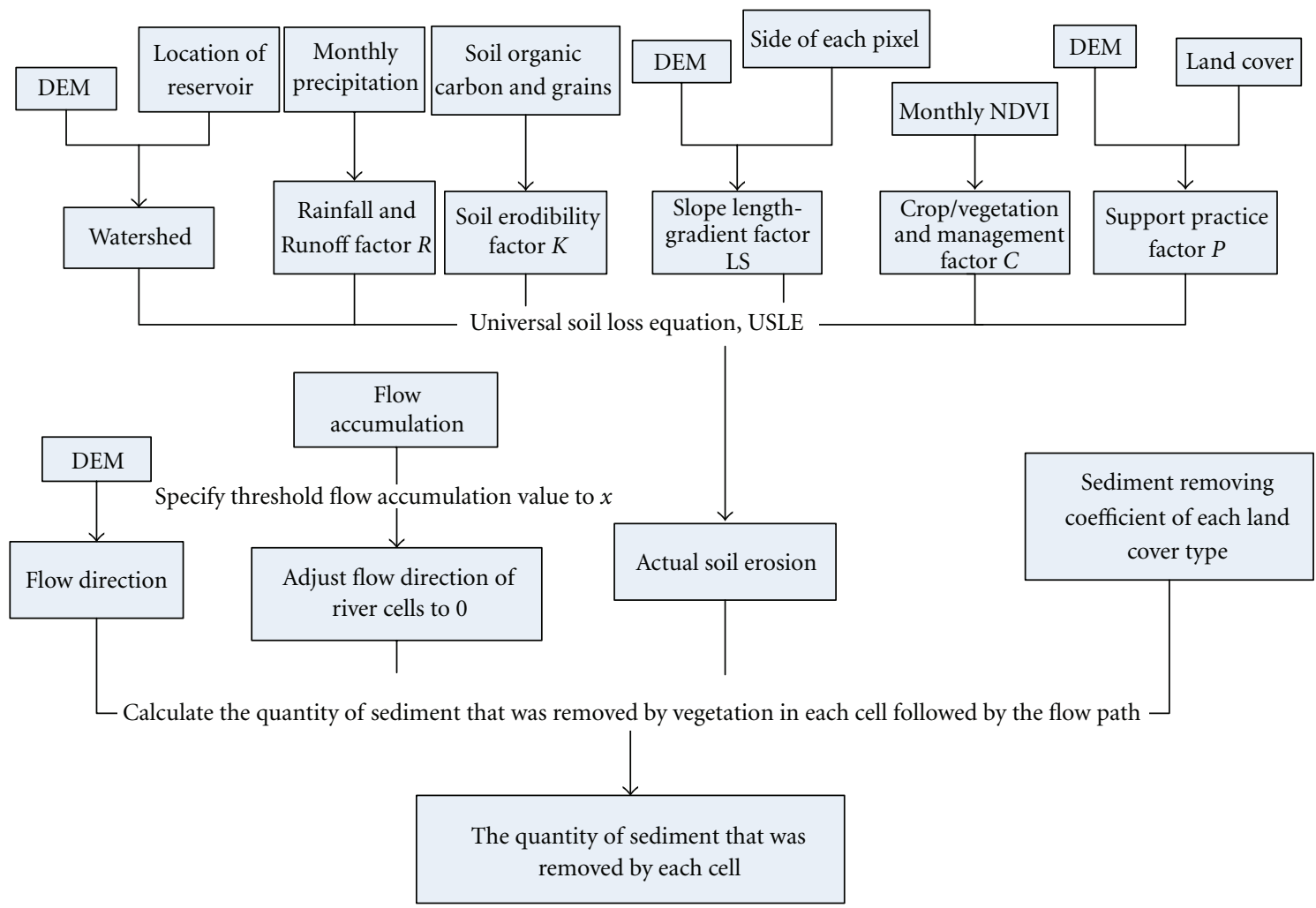

FIgURE 2: The flow chart of mapping biophysical assessment.

as given by geographic location $\left(\mathrm{MJ} \cdot \mathrm{mm} \cdot \mathrm{hm}^{-2} \cdot \mathrm{h}^{-1} \cdot \mathrm{a}^{-1}\right)$, $K$ is the soil erodibility factor $\left(\mathrm{t} \cdot \mathrm{h} \cdot \mathrm{MJ}^{-1} \cdot \mathrm{mm}^{-1}\right), L S$ is the slope length-gradient factor, $C$ is the crop/vegetation and management factor, and $P$ is the support practice factor. The computational formulae for each factor are selected based on the specific conditions of the study area.

The simple algorithm proposed by Zhang and $\mathrm{Fu}$ [13] is used to calculate the rainfall and runoff factor $R$ :

$$
\begin{gathered}
R=\alpha F^{\beta}, \\
F=1 \cdot N^{-1} \sum_{i=1}^{N}\left[\left(\sum_{j=1}^{12} P_{i, j}^{2}\right) \cdot\left(\sum_{j=1}^{12} P_{i, j}\right)^{-1}\right] .
\end{gathered}
$$

In this formula, $P_{i, j}$ is the monthly precipitation in month $j$, year $i(\mathrm{~mm}), N$ is the number of years, $R$ is the average annual rainfall and runoff factor $\left(\mathrm{MJ} \cdot \mathrm{mm} \cdot \mathrm{hm}^{-2}\right.$. $\mathrm{h}^{-1} \cdot \mathrm{a}^{-1}$ ), and $\alpha$ and $\beta$ are parameters in this model (the value of $\alpha$ is 0.1833 and that of $\beta$ is 1.9957 ). The precipitation data in this formula were supplied by the China Meteorological Administration for the year 2005. The data set contains latitude, longitude, and altitude for 743 weather stations in China (57 stations cover the Yalong River basin). The monthly precipitation $(\mathrm{mm})$ for each weather station is also included. The Kriging interpolation analysis method is used. The cell size of the output raster is set to $1 \mathrm{~km} \times 1 \mathrm{~km}$.

The method in the erosion-productivity impact calculator (EPIC) model proposed by Williams et al. [14] is used to estimate the soil erodibility factor $K$. It can estimate the $K$ factor just from the data of the soil grains containing organic carbon:

$$
\begin{aligned}
K= & \left\{0.2+0.3 \times \exp \left[-0.0256 \times S_{d} \times\left(1-\frac{S_{l}}{100}\right)\right]\right\} \\
& \times\left[\frac{S_{l}}{\left(C_{l}+S_{l}\right)}\right]^{0.3} \\
& \times\left\{1.0-\frac{0.25 \times C}{[C+\exp (3.72-2.95 \times C)]}\right\} \\
& \times \frac{\left[1.0-0.7 \times\left(1-S_{d} / 100\right)\right]}{\left\{1-S_{d} / 100+\exp \left[-5.51+22.9 \times\left(1-S_{d} / 100\right)\right]\right\}} .
\end{aligned}
$$

In this formula, $K$ is the soil erodibility factor in English units, it is transformed to international units by multiplying by $0.132\left(\mathrm{t} \cdot \mathrm{h} \cdot \mathrm{MJ}^{-1} \cdot \mathrm{mm}^{-1}\right), S_{d}$ is the content of sand grains $(\%), S_{1}$ is the content of powder grains (\%), $C_{l}$ is the content of clay grains (\%), and $C$ is the content of organic carbon (\%). The soil data in this formula came from the Chinese digital soil map (scale 1:1000000) of the Data Center for Resources and Environmental Sciences Chinese, Academy of Sciences (RESDC). It contains the physics and chemistry attributes database of different soil types. 
The slope length-gradient factor $L S$ contains the lengthgradient factor and the slope factor. The method proposed by Wischmeier and Smith [15] is used:

$$
L S_{i}=\left(\frac{l_{i}}{22}\right)^{0.3} \times\left(\frac{\theta_{i}}{5.16}\right)^{1.3}
$$

In this formula, $L S_{i}$ is the $L S$ factor in the pixel $i, l_{i}$ is the length-gradient in the pixel $i(\mathrm{~m})$, and $\theta_{i}$ is the slope in pixel $i$ $\left({ }^{\circ}\right)$. The slope datum is derived from the DEM (the cell size is $30 \mathrm{~m}$ ). The length-gradient datum is derived from the aspect, slope, and cell size of the raster.

The crop/vegetation and management factor $C$ is estimated based on vegetation coverage $[16,17]$ :

$$
\begin{gathered}
C=1 \quad f_{v} \leq 0.1 \%, \\
C=0.6508-0.3436 \lg f_{v} \quad 0.1 \%<f_{v}<78.3 \%, \\
C=0 \quad f_{v} \geq 78.3 \% .
\end{gathered}
$$

In this formula, $f_{v}$ is the annual vegetation coverage (\%). There is a relationship between the regional vegetation coverage and the normalized difference vegetation index (NDVI) based on Gutman's research [18]:

$$
f_{v}=\frac{\mathrm{NDVI}-\mathrm{NDVI}_{\min }}{\mathrm{NDVI}_{\max }-\mathrm{NDVI}_{\min }} .
$$

In this formula, $\mathrm{NDVI}_{\max }$ and $\mathrm{NDVI}_{\min }$ are the maximum and minimum of the NDVI in the growing season for each vegetation type. The NDVI data for the year 2005 in this formula came from the Chinese Environment Investigation Database. The cell size is $1 \mathrm{~km} \times 1 \mathrm{~km}$. The time resolution is a month. The raster data format is a GRID.

The support practice factor $P$ represents the influence that the soil and water conservation measures have on soil erosion. If cultivated land at the same elevation, such as terraced fields or strip cultivation, and other relative control measures are used, the $P$ value is less than 1 . If the study area is covered by natural vegetation and sloping farmland, the $P$ value is equal to 1 . The $P$ factor is determined by the DEM and the land use data for the watershed (for the year 2005 and at a scale of $1: 100000$ ).

\subsubsection{Spatial Variability of Sediment Intercepted by Vegetation.} The sediment that minor landscape units export may occupy most of the sediment loads in the outlet of the whole watershed while it has or exercises a determining influence on receiving water body sedimentation. These regions become of the critical source regions which caused the relative reservoir sedimentation in the lower reaches of a river. This compared with some landscape units may only export a small bit of sediment or some even become of sinks for sediment.

The quantity of sediment intercepted by vegetation in watershed is the biophysical quantity for the ecosystem service of preventing sediment from entering the outlet of watershed. It can be obtained from the actual soil erosion simulated by USLE and sediment retention coefficient of different land cover types. The sediment retention coefficient (values range from 0 to 1 , the value approaches 1 means excellent ability of sediment retention in specific land cover types) expresses the proportion of sediment that is intercepted by passing through land cover during its delivery path. The coefficient was set by referring to the development of research abroad about the sediment in surface runoff removed by different types of vegetation buffer [19-24] due to the many impacts of this coefficient on one hand and a dearth of relative research achievements in this region on the other hand. In the watershed of Ertan reservoir, the sediment retention coefficient in forestland was set to 0.87 , in grassland to 0.73 , in farmland to 0.60 , and in build-up and wasteland to 0.40 .

Every pixel has its flow path that it flows from the top of drainage basin to the outlet of watershed on hydrological surface. Based on the flow accumulation data (cell size is $30 \mathrm{~m}$ ) derived from DEM, the pixels that flow accumulation was above 30000 cells were identified to river and the relative flow direction was set to zero that means flat by integrating the distribution of real river course in study watershed. Each pixel in the watershed will search and flow into the next neighbor pixel according to flow direction data till flowing into river course (see Figure 3(a)). The quantity of sediment retention by vegetation in each pixel $i\left[\mathrm{t} /\left(\mathrm{km}^{2} \cdot \mathrm{a}\right)\right]$ will be simulated based on the calculation model of the first four cells by inference that were listed in Table 1. The biophysical assessment of the avoided reservoir sedimentation ecosystem service in each pixel and the relative spatial distribution map were obtained.

2.3. The Evaluation Model on Value. The evaluation model on value for preventing the sediment from entering the reservoir in each pixel in a watershed is calculated by the formula as follows:

$$
\begin{aligned}
\text { Value }_{S R_{i}}= & \left(\sum_{t=1}^{T-1} \frac{S R_{i} \times M C}{(1+r / 100)^{t}}\right) \\
& +\frac{\left[S R_{i}+\left(\mathrm{Vol}_{\text {current }}-\mathrm{Vol}_{\text {dead }}\right)\right] \times M C}{(1+r / 100)^{0}} .
\end{aligned}
$$

In this formula, Value $S_{S}$ is the value of preventing the sediment from entering the reservoir per pixel $i$ in the remaining designed lifetime of the structure in the watershed (Yuan), $S R_{i}$ is the annual quantity of the sediment prevented from entering the reservoir per pixel $i\left(\mathrm{t} \cdot \mathrm{a}^{-1}\right)$, and $M C$ is the cost of the sediment removed from the study reservoir in yuan per ton (yuan $\cdot \mathrm{t}^{-1}$ ). If the Ertan reservoir uses the sediment removal method of dredging the disturbed sand at the bottom of reservoir, for the purpose of the economic analysis the cost of sediment removal per unit volume is about 0.55 Yuan $\cdot \mathrm{m}^{-3}$ [25]. The density of the sediment is about $1.35 \mathrm{t} \cdot \mathrm{m}^{-3}$. So the cost of sediment removal in Yuan per ton is about 0.407 Yuan $\cdot \mathrm{t}^{-1} \cdot r$ is the market discount rate (\%), which reflects society's preference for immediate benefits over future benefits. The latest market discount rate in China is used by referring to the Chinese Bill Net (http://www.zgpj.net/). $T$ is the remaining designed lifetime of the structure (a). $\operatorname{Vol}_{\text {current }}$ is the current volume of the sediment in the reservoir $(\mathrm{t})$. $\mathrm{Vol}_{\text {dead }}$ is the volume of the 


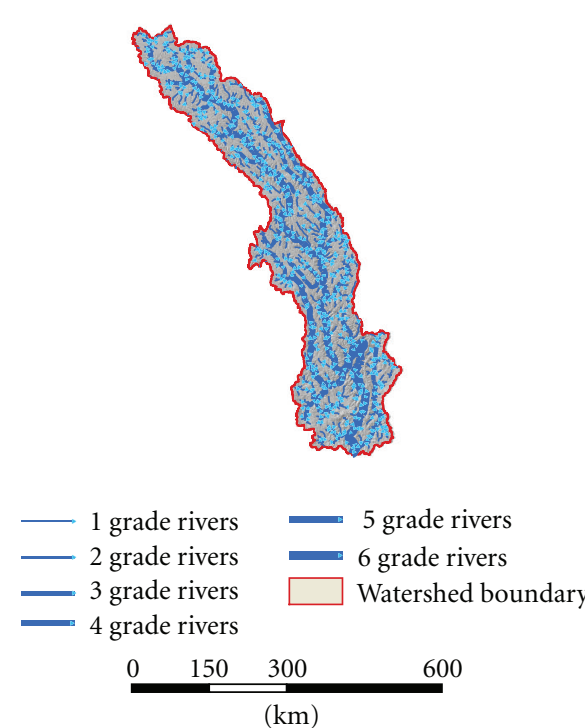

(a)
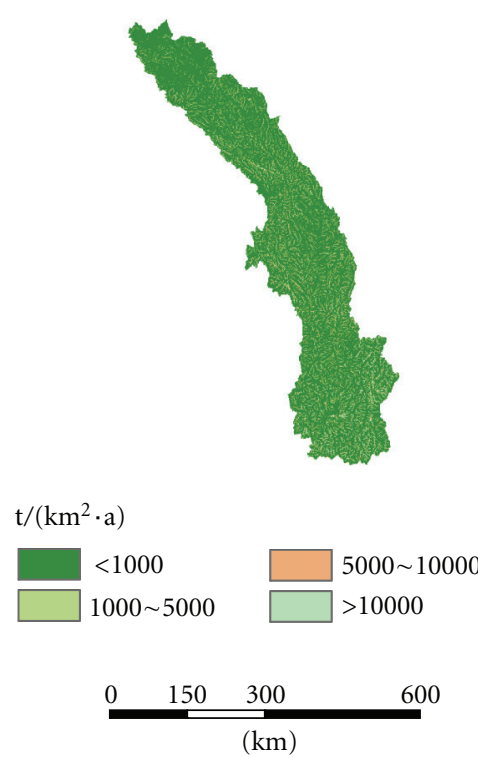

(c)

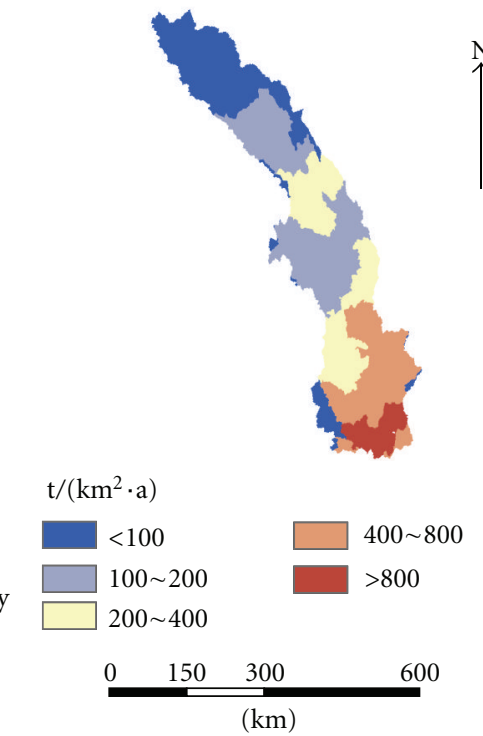

(b)
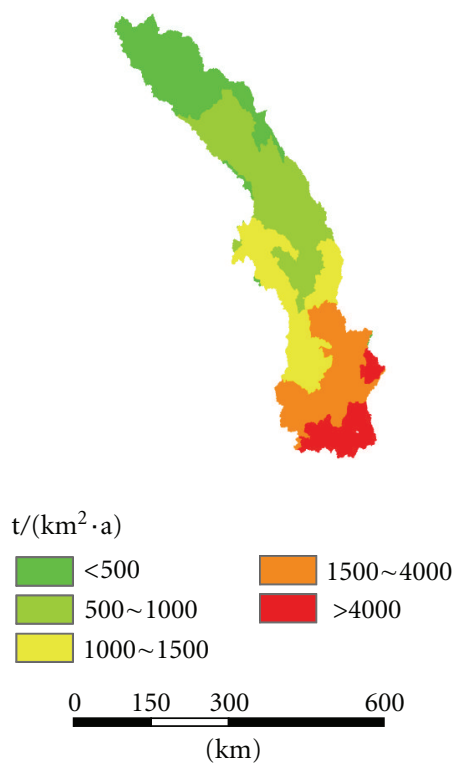

(d)

FIgURE 3: Spatial distributions of exporting sediment to Ertan reservoir and sediment retention of ecosystem in watershed. (a) The process of flow accumulation. (b) Average exporting sediment to Ertan reservoir of each county in 2005. (c) Sediment retention in 2005. (d) Average sediment retention of each county in 2005.

sediment in the reservoir at which its function is adversely affected ( $\mathrm{t}$ ). If no account is taken of the $\mathrm{Vol}_{\text {current }}$ and $\mathrm{Vol}_{\text {dead }}$, and the ecosystem service value is assessed only in the present year, the evaluation model on value can be simplified as follows:

$$
\text { Value }_{S R_{i}}=S R_{i} \times M C \text {. }
$$

\section{Results and Analysis}

3.1. The Soil Erosion and Sediment Delivery in Different Land Cover Types. Table 2 demonstrated the area and its proportion of different land cover types in watershed of Ertan reservoir in 2005. The dominant ecosystem types are grassland, forestland, and wasteland. The three areas account for $93.3 \%$ of the watershed total land area.

The total amount of actual soil erosion in the watershed was $2.337 \times 10^{8} \mathrm{t} \cdot \mathrm{a}^{-1}$ in 2005 based on formulae (1). The amount level of average actual soil erosion in a unit area on different land cover types in watershed was expressed by farmland $\gg$ build-up and wasteland $>$ forestland and grassland. The average actual soil erosion per unit area in farmland was $187.5 \times 10^{2} \mathrm{t} \cdot \mathrm{km}^{-2} \cdot \mathrm{a}^{-1}$. This is larger because the $C P$ factor in these ecosystem types is larger. Although the 
TABLE 1: The model of calculating the quantity of sediment retention by vegetation in each cell followed by the flow path.

\begin{tabular}{|c|c|c|c|c|}
\hline Cell ID & $\begin{array}{l}\text { Sediment retention } \\
\text { coefficient } \\
\text { (no unit) }\end{array}$ & $\begin{array}{c}\text { Actual soil loss } \\
{\left[\mathrm{t} /\left(\mathrm{km}^{2} \cdot \mathrm{a}\right)\right]}\end{array}$ & $\begin{array}{c}\text { The quantity of sediment } \\
\text { retention by vegetation } \\
{\left[\mathrm{t} /\left(\mathrm{km}^{2} \cdot \mathrm{a}\right)\right]}\end{array}$ & $\begin{array}{l}\text { The quantity of sediment that } \\
\text { was passed to the next cell } \\
{\left[\mathrm{t} /\left(\mathrm{km}^{2} \cdot \mathrm{a}\right)\right]}\end{array}$ \\
\hline 1 & $R_{1}$ & USLE1 & 0 & USLE1 \\
\hline 2 & $R_{2}$ & USLE2 & USLE $1 \times R_{2}$ & USLE1 $\times\left(1-R_{2}\right)+$ USLE2 \\
\hline 3 & $R_{3}$ & USLE3 & {$\left[\mathrm{USLE} 1 \times\left(1-R_{2}\right)+\mathrm{USLE} 2\right] \times R_{3}$} & $\begin{array}{c}\left.\text { [USLE } 1 \times\left(1-R_{2}\right)+\text { USLE2 }\right] \times \\
\left(1-R_{3}\right)+\text { USLE } 3\end{array}$ \\
\hline 4 & $R_{4}$ & USLE4 & $\begin{array}{c}\left\{\left[\text { USLE } 1 \times\left(1-R_{2}\right)+\text { USLE2 }\right] \times\right. \\
\left.\quad\left(1-R_{3}\right)+\text { USLE } 3\right\} \times R_{4}\end{array}$ & $\begin{array}{c}\left\{\left[\text { USLE } 1 \times\left(1-R_{2}\right)+\right.\right. \\
\left.\text { USLE } 2] \times\left(1-R_{3}\right)+\text { USLE } 3\right\} \times \\
\left(1-R_{4}\right)+\text { USLE } 4\end{array}$ \\
\hline
\end{tabular}

Note: it assumes that the first cell does not intercept the eroded soil which occurs by itself.

area of farmland only covers around $6.0 \%$ of the watershed total land area, its contribution to the total amount of actual soil erosion was the highest (more than half of the total), reaching $1.43 \times 10^{8} \mathrm{t} \cdot \mathrm{a}^{-1}$. It is worthwhile to note that the average actual soil erosion per unit area in build-up also had a high value in comparison. That was because the pressure of the continuous population growth in mountain area aggravated the contradictions between the land and our human beings. The actual increase in build-up was most located in these regions where there were higher elevation deviate degree and steep slope. So the LS factor in build-up had a certain degree of promotion.

According to the model of calculating the quantity of sediment retention by vegetation in each cell followed by the flow path in Table 1, the quantity of sediment export to Ertan reservoir in each pixel could also be calculated. The total amount of sediment export in the watershed reached 3822.54 $\times 10^{4} \mathrm{t} \cdot \mathrm{a}^{-1}$ in 2005 . The amount level of average exporting sediment to reservoir in a unit area on different land cover types in watershed was expressed by farmland $>$ build-up $>$ grassland $>$ wasteland $>$ forestland. Taking irrigation and hydrological conditions into consideration, the farmland was most located near water resources and was close to river course correspondingly. So a great deal of eroded soil in farmland would not be intercepted efficiently by different types of ecosystems in the process of sediment delivery in a watershed. The average exporting sediment to reservoir in a unit area in farmland was the highest. The total amount of sediment export to Ertan reservoir in farmland reached $2645.05 \times 10^{4} \mathrm{t} \cdot \mathrm{a}^{-1}$ in 2005 . It occupied $69.2 \%$ of the whole watershed. So it was obvious that farmland was the most important source of sediment yield to Ertan reservoir. If the area and tilling intensity of farmland distributed in sloping fields near the river course is not constrained, it will generate acute soil erosion and a mass of sediment to the reservoir, which worsens the environmental problems. In big river bend of Yalong River basin and counties around Ertan reservoir, the farmland that was widely distributed in hydrological sensitive area caused the quantity of sediment exporting rose steeply (see Figure 1 and Figure 3(b)). While the forestland was most located in the middle and upper Yalong River basin, the most eroded soil was intercepted better in the longer flow path. Therefore, the average sedi- ment exporting to reservoir in a unit area in forestland was the lowest $\left(45.8 \mathrm{t} \cdot \mathrm{km}^{-2} \cdot \mathrm{a}^{-1}\right)$.

3.2. The Sediment Retention and Its Economic Value in Different Land Cover Types. The quantity of sediment retention that is the biophysical assessment of the ecosystem service of preventing sediment from entering Ertan reservoir on 5 different ecosystem types for the whole of the watershed in 2005 was simulated using the model listed in Table 1. The results indicated that the total amount of sediment retention was $1.94 \times 10^{8} \mathrm{t} \cdot \mathrm{a}^{-1}$ in 2005 which occupied $83.01 \%$ of the total amount of soil erosion. So most eroded soil was intercepted by different types of ecosystems in the process of sediment delivery in a watershed. The ability of sediment retention in surface runoff in forestland and grassland was the strongest. But their relative ecosystem service was not brought into full play because they were located in the region where the slope is steep, the elevation is high, and the distance is far from river course primarily. The average sediment retention in a unit area of forestland and grassland was only 1705.7 and $940.2 \mathrm{t} \cdot \mathrm{km}^{-2} \cdot \mathrm{a}^{-1}$, respectively. Therefore, forest or shrub belt should be planted along the banks of ponds, streams, and valleys as well as at the runoff intersection of slope bottom in the future. The bended structure grassland should be set near sloping fields reasonably. These vegetational buffer zones could bring their abilities of sediment retention into fullest play in watershed. The absolute quantity of average sediment retention in farmland was the highest $\left(6525.0 \mathrm{t} \cdot \mathrm{km}^{-2} \cdot \mathrm{a}^{-1}\right)$ because it is most located in the region where the soil erosion is serious. The average sediment exporting and retention in a unit area of the increased build-up in a mountainous area were high as well because the increased soil erosion occurs in this land cover type.

The high value of average sediment retention of each county was concentrated in the lower reaches of Yalong River basin in 2005 (see Figure 3(d)). These counties where average sediment retention was above $4000 \mathrm{t} \cdot \mathrm{km}^{-2} \cdot \mathrm{a}^{-1}$ were concentrated around the Ertan reservoir. They were Huaping, Yanbian, Miyi, Huili, and Dechang counties. Therefore, human activity and what it brings to the land use and cover changes (LUCCs) near the reservoir need to be considered. This was a major source of sediment generation which should be monitored and managed carefully. 
TABLE 2: The average soil erosion, exporting sediment and sediment retention of different types of land cover in 2005.

\begin{tabular}{lccccc}
\hline Land cover types & Area $\left(\mathrm{km}^{2}\right)$ & $\begin{array}{c}\text { Area percent } \\
(\%)\end{array}$ & $\begin{array}{c}\text { Average actual soil erosion } \\
\text { in a unit area }\left[\times 10^{2}\right. \\
\left.\mathrm{t} /\left(\mathrm{km}^{2} \cdot \mathrm{a}\right)\right]\end{array}$ & $\begin{array}{c}\text { Average exporting } \\
\text { sediment to reservoir in a } \\
\text { unit area }\left[\mathrm{t} /\left(\mathrm{km}^{2} \cdot \mathrm{a}\right)\right]\end{array}$ & $\begin{array}{c}\text { Average sediment retention } \\
\left.\text { in } \mathrm{a} u \text { unit area }\left[\mathrm{t} /(\mathrm{km})^{2} \cdot \mathrm{a}\right)\right]\end{array}$ \\
\hline Farmland & 7610.7 & 6.0 & 187.5 & 3475.4 & 6525.0 \\
Forestland & 48307.5 & 37.8 & 3.8 & 45.8 & 1705.7 \\
Grassland & 62238.5 & 48.7 & 8.9 & 138.3 & 940.2 \\
Build-up & 177.5 & 0.1 & 19.5 & 772.5 & 4499.5 \\
Wasteland & 9499.1 & 7.4 & 17.7 & 86.5 & 259.1 \\
\hline
\end{tabular}

TABLE 3: Economic value of avoided reservoir sedimentation of different types of land cover in 2005.

\begin{tabular}{lccc}
\hline $\begin{array}{l}\text { Land cover } \\
\text { types }\end{array}$ & $\begin{array}{c}\text { Area percent } \\
(\%)\end{array}$ & $\begin{array}{c}\text { Average value in a } \\
\text { unit area }\left[\times 10^{4}\right. \\
\mathrm{RMB} \\
\left.\text { Yuan } /\left(\mathrm{km}^{2} \cdot \mathrm{a}\right)\right]\end{array}$ & $\begin{array}{c}\text { Total value } \\
\left(\times 10^{8} \mathrm{RMB}\right. \\
\text { Yuan/a })\end{array}$ \\
\hline Farmland & 6.0 & 265.6 & 202.7 \\
Forestland & 37.8 & 69.4 & 333.5 \\
Grassland & 48.7 & 38.3 & 236.3 \\
Build-up & 0.1 & 183.1 & 3.3 \\
Wasteland & 7.4 & 10.5 & 10.0 \\
\hline Total & 100 & & 785.8 \\
\hline
\end{tabular}

The results showed that the two dominant ecosystem types in total value of the avoided reservoir sedimentation in the watershed were forestland and grassland in 2005 (see Table 3). The ecosystem service value of forestland and grassland accounted for $89.98 \%$ of the total value of the watershed. The average ecosystem service value per unit area of farmland, build-up, and forestland areas was the highest. The total value of the avoided Ertan reservoir sedimentation in the watershed was $785.8 \times 10^{8}$ Yuan in 2005 .

\section{Conclusion and Discussion}

In China, the biophysical and valuation assessment of ecosystem service was a rough estimate based on relative coefficient of different types of ecosystem primarily. This situation gradually turned into studying the relationship between the relative ecological process and the ability of ecosystem service in a deep-going way. Therefore, against this background, studying the correlation and complicated relationship among the pattern of ecosystem, ecosystem service, and ecological process has become a hot topic of ecosystem service in the future [7]. This study took the ecosystem service of avoided reservoir sedimentation as the research object. The biophysical and valuation models were established based on the land cover pattern and process of sediment retention and they have been studied and applied by taking the land cover pattern — relative biophysical process-ecosystem service as the storyline. The prospect of this research can set a series of land cover scenarios by integrating land use planning in study watershed. The responses of the ecosystem services and its economic value to future land use/cover pattern scenarios were studied. The service benefit of various pattern scenarios was weighed and the scenario which let the well-being of the related groups be maximal increase was selected.

Some limitations and simplifications also existed in the model and relative case study which needed to be perfected.

(1) The simulated results are the quantity and the spatial distribution of preventing the sediment from entering the reservoir in the watershed. So this model does not take the regulation of sediment movement to the lower river into account. In practice, a part of the sediment will be deposited in the reservoir (it is mainly bed load and suspended load) and another part of the sediment will move to the lower river regions over time. Future research will survey the actual sedimentation behavior of a specific reservoir. In order to evaluate the ecosystem service thoroughly, we should ascertain the ratio of sediment delivered to the lower river to the total sediment entering the reservoir.

(2) The types of erosion in the study area include sheet erosion and river course erosion (belong to water erosion) as well as mass erosion. The USLE equation that we used considers only sheet erosion. It simplifies the model but increases the difficulty of validating the model while reducing the precision of the validation process. The research for the future will examine the addition of a module that can simulate sediment generated by river course erosion and by mass erosion in the evaluation model.

(3) This research was intended to analyze the responses of the sediment delivery process to the pattern of underlying surface in watershed in regional scale. However, it was undeniable that there are high correlations between the process of sediment delivery and the climate situation especially in storm intensity. Therefore, uncertainty was generated in analyzing the process of sediment retention and delivery due to the difference of precipitation state. Eliminating the effect of climate situation on the process of sediment delivery is beyond the horizon of present knowledge. We should delve into this area by combination of factors of upscaling methods and space information technology based on the experiment and mechanism investigation on typical subdistricts. 
(4) The factors affecting sediment retention coefficient of different land cover types in watershed were many (precipitation — runoff factor, sediment source, texture, channel density, etc. are all included). It was very hard to establish a synthetic model that includes all the factors for accurate coefficient setting. This case merely sets the coefficient simply by consulting achievements in scientific research in the existing literature home and abroad. This model simulated the actual soil erosion based on the USLE. The simulated results should be validated and revised by direct measurements of the actual quantities of soil erosion because the USLE behaves differently in different study areas. The simulated results showed that the total amount of sediment exporting to Ertan reservoir was $3822.54 \times 10^{4} \mathrm{t} \cdot \mathrm{a}^{-1}$ in 2005 . However, according to the field measured data of Xiaodeshi hydrological station in recent years in Yalong River basin, the average annual amount of suspended load was $2720 \times 10^{4} \mathrm{t}$ while the bed load was $67 \times 10^{4} \mathrm{t}$. Therefore, the total amount of sediment exporting was $2787 \times 10^{4} \mathrm{t}$ [26]. There were some differences between the simulated results and measured data. The types of ecosystem should be divided accurately by integrating the vegetation coverage, land use degree and sediment texture, and so forth. In order to simulate more accurately, the various relative coefficients need to be adjusted based on the basic study on mechanism and observation in typical subdistricts.

\section{Foundation Items}

UNEP/GEF Nature Conservation and Flood Control in the Yangtze River Basin (IMIS: GFL-2328-2740-4822; PMS: GF/3030-04-05-01); National Public Beneficial Scientific Research on Environmental Protection (200709029); The Natural Capital Project.

\section{References}

[1] H. T. Tian, Z. K. Zhang, Y. M. Li et al., "Differences in reservoir sedimentation in inland China," Advances in Science and Technology of Water Resources, vol. 26, no. 6, pp. 28-33, 2006 (Chinese).

[2] W. H. Li, Theories, Methods and Applications of Evaluation on Ecosystem Functions and Services, People's University of China Press, Beijing, China, 2008.

[3] Z. Y. Ouyang, X. K. Wang, H. Miao et al., "A primary study on Chinese terrestrial ecosystem services and their ecologicaleconomic values," Acta Ecologica Sinica, vol. 19, no. 5, pp. 607613, 1999 (Chinese).

[4] Y. Xiao, G. D. Xie, K. An et al., "The function and economic value of soil conservation of ecosystems in Qinghai-Tibet Plateau," Acta Ecologica Sinica, vol. 23, no. 11, pp. 2367-2378, 2003 (Chinese).

[5] M. C. Liu, D. Q. Li, Y. M. Wen, and X. F. Luan, "The spatial analysis of soil retention function in Sanjiangyuan region and its value evaluation," Zhongguo Huanjing Kexue/China
Environmental Science, vol. 25, no. 5, pp. 627-631, 2005 (Chinese).

[6] Ministry of Water Resources of China, Chinese Water Resources Statistical Yearbook, China Water Resources Press, Beijing, China, 1992.

[7] G. D. Xie, Y. Xiao, and C. X. Lu, "Study on ecosystem services: progress, limitation and basic paradigm," Journal of Plant Ecology, vol. 30, no. 2, pp. 191-199, 2006.

[8] H. L. Sun, Ecological and Environmental Problems in the Upper Yangtze River, China Environmental Sciences Press, Beijing, China, 2008.

[9] N. Sun, X. D. Li, H. C. Li et al., Dictionary of Geography, Shanghai Dictionary Press, Shanghai, China, 1983.

[10] G. A. Tang and X. Yang, The Experiment Tutorial of Using ArcGIS for Spatial Analysis, Science Press, Beijing, China, 2006.

[11] S. J. Walsh, "Geographic information systems for natural resource management," Journal of Soil and Water Conservation, vol. 40, no. 2, pp. 202-205, 1985.

[12] A. Lufafa, M. M. Tenywa, M. Isabirye, M. J. G. Majaliwa, and P. L. Woomer, "Prediction of soil erosion in a Lake Victoria basin catchment using a GIS-based universal soil loss model," Agricultural Systems, vol. 76, no. 3, pp. 883-894, 2003.

[13] W. B. Zhang and J. S. Fu, "Rainfall erosivity estimation under different rainfall amount," Resources Science, vol. 25, no. 1, pp. 35-41, 2003 (Chinese).

[14] J. R. Williams, K. G. Renard, and P. T. Dyke, "EPIC: a new method for assessing erosion's effect on soil productivity," Journal of Soil and Water Conservation, vol. 38, no. 5, pp. 381383, 1983.

[15] W. H. Wischmeier and D. D. Smith, Predicting Rainfall Erosion Losses - A Guide to Conservation Planning: Agriculture Handbook, USDA, Washington, DC, USA, 1978.

[16] C. F. Cai, S. W. Ding, Z. H. Shi et al., "Study of applying USLE and geographical information system IDRISI to predict soil erosion in small watershe," Journal of Soil and Water Conservation, vol. 14, no. 2, pp. 19-24, 2000 (Chinese).

[17] C. F. Ma, J. W. Ma, and A. Buhe, "Quantitative assessment of vegetation coverage factor in USLE model using remote sensing data," Bulletin of Soil and Water Conservation, vol. 21, no. 4, pp. 6-9, 2001 (Chinese).

[18] G. Gutman and A. Ignatov, "The derivation of the green vegetation fraction from NOAA/AVHRR data for use in numerical weather prediction models," International Journal of Remote Sensing, vol. 19, no. 8, pp. 1533-1543, 1998.

[19] J. M. Sheridan, R. Lowrance, and D. D. Bosch, "Management effects on runoff and sediment transport in riparian forest buffers," Transactions of the American Society of Agricultural Engineers, vol. 42, no. 1, pp. 55-64, 1999.

[20] J. R. Cooper and J. W. Gilliam, "Phosphorus redistribution from cultivated fields into riparian areas," Soil Science Society of America Journal, vol. 51, no. 6, pp. 1600-1604, 1987.

[21] R. Lowrance, J. K. Sharpe, and J. M. Sheridan, "Long-term sediment deposition in the riparian zone of a coastal plain watershed," Journal of Soil and Water Conservation, vol. 41, no. 4, pp. 266-271, 1986.

[22] W. L. Magette, R. B. Brinsfield, R. E. Palmer, and J. D. Wood, "Nutrient and sediment removal by vegetated filter strips," Transactions of the American Society of Agricultural Engineers, vol. 32, no. 2, pp. 663-667, 1989.

[23] R. B. Daniels and J. W. Gilliam, "Sediment and chemical load reduction by grass and riparian filters," Soil Science Society of America Journal, vol. 60, no. 1, pp. 246-251, 1996. 
[24] L. G. Wilson, "Sediment removal from flood water by grass filtration," Transactions of the American Society of Agricultural Engineers, vol. 10, pp. 35-37, 1967.

[25] M. Q. Gen, "Analyse on the project of removing sediment of Xiaolangdi reservoir in Yellow River: the key technology and equipment of dealing with sediment in Xiaolangdi reservoir workshop," Xiaolangdi, pp. 72-79, 2006 (Chinese).

[26] Y. S. Guo, Z. S. Yu, D. C. Chen et al., "The environment of Ertan hydroelectric station and the reservoir area," Journal of Sichuan Teachers College (Natural Science), vol. 19, no. 1, pp. 9-15, 1998 (Chinese). 

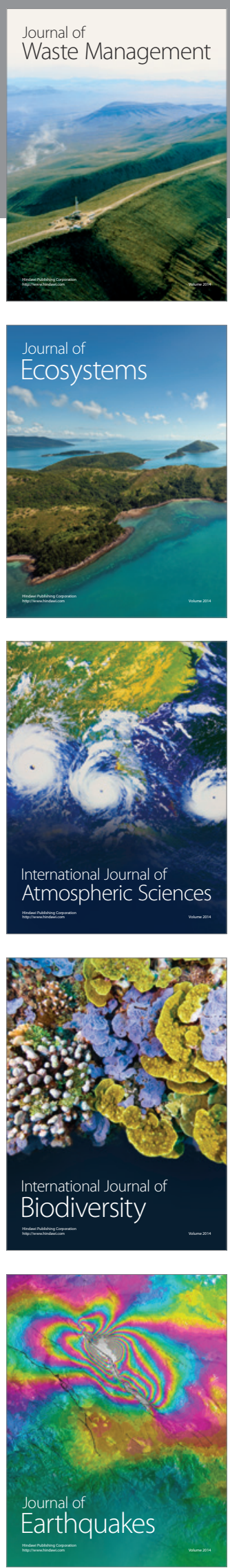
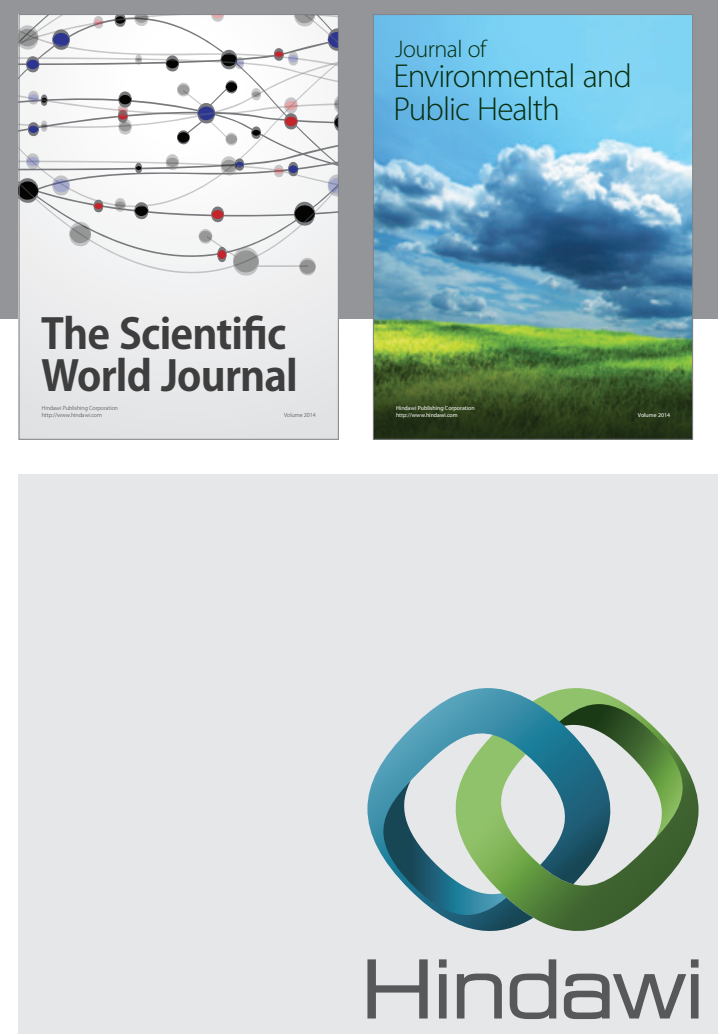

Submit your manuscripts at

http://www.hindawi.com
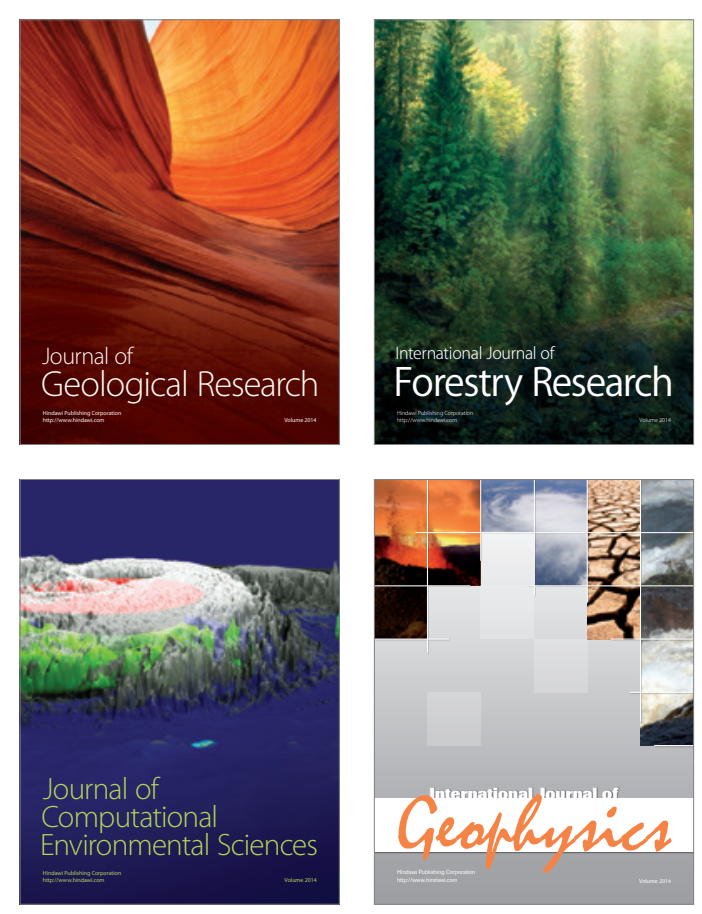
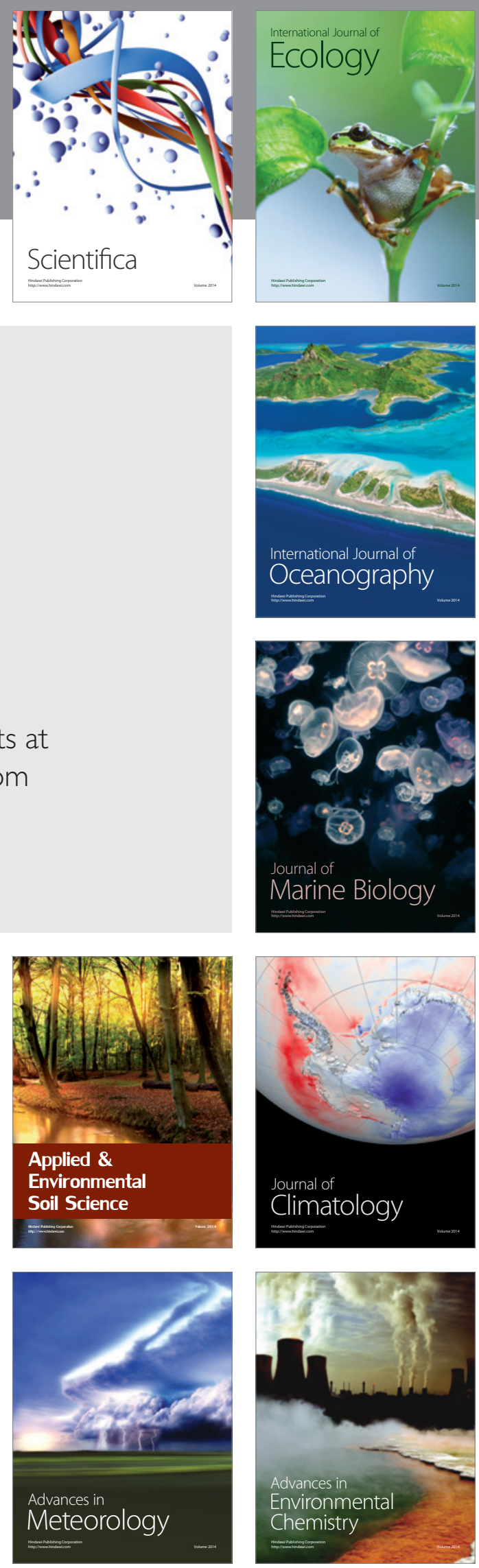